\title{
The Brazilian Neurology centenary
}

\section{(1912-2012) and the common origin of the fields of Neurology and Psychiatry}

\author{
O centenário da Neurologia brasileira (1912-2012) e a origem comum das áreas de \\ Neurologia e Psiquiatria
}

Marleide da Mota Gomes', Jose Luiz de Sá Cavalcanti²

\begin{abstract}
It is reported the Brazilian Neurology birth (1912), that has as the hallmark its first Neurology Cathedra of Rio de Janeiro, and the links between Neurology and Psychiatry, besides the main medical protagonists at that time in Rio de Janeiro: João Carlos Teixeira Brandão (18541921), first professor of the cathedra of Clinical Psychiatry and Nervous Diseases (1883-1921); Juliano Moreira (1873-1933), the founder of the Brazilian scientific Psychiatry and director of the Hospício Nacional de Alienados (National Hospice for the Insane) (1903-1930); Antônio Austregésilo Rodrigues de Lima (1876-1960), first professor of the cathedra of Neurology, considered the father of the Brazilian Neurology. Aloysio de Castro (1881-1959) was a great Brazilian neurosemiologist at that time. Austregésilo practiced both disciplines, Neurology and Psychiatry, and like Jean-Martin-Charcot, he was very interested in a typically psychiatric disorder, the hysteria. It is also considered in this paper the first Brazilian authors of Neurology and/or Psychiatric texts and the places where Neurology was initially developed by the main founders: Hospício Nacional de Alienados, Santa Casa de Misericórdia do Rio de Janeiro and Policlínica Geral do Rio de Janeiro.
\end{abstract}

Key words: brazilian neurology, psychiatry, neuropsychiatry, history of neurosciences.

\section{RESUMO}

É relatado o nascimento da Neurologia brasileira (1912), que tem como marco principal a primeira Cátedra de Neurologia do Rio de Janeiro, bem como as ligações entre Neurologia e Psiquiatria, além dos principais protagonistas médicos da época naquela cidade: João Carlos Teixeira Brandão (1854-1921), primeiro professor da cátedra da Clínica psiquiátrica e de moléstias nervosas (1883-1921); Juliano Moreira (1873-1933), fundador da Psiquiatria científica brasileira e diretor do Hospício Nacional dos Alienados (1903-1930); Antônio Austregésilo Rodrigues de Lima (1876-1960), primeiro catedrático de Neurologia, considerado o pai da Neurologia brasileira. Aloysio de Castro (18811959) foi um grande neurosemiologista brasileiro da época. Austregésilo praticava tanto a Neurologia quanto a Psiquiatria e, como Jean Martin-Charcot, estava muito interessado em um típico transtorno psiquiátrico, a histeria. Consideram-se também os primeiros autores brasileiros de textos de Neurologia e/ou Psiquiatria e os locais onde a Neurologia foi inicialmente desenvolvida pelos fundadores principais: Hospício Nacional dos Alienados, Santa Casa de Misericórdia do Rio de Janeiro e Policlínica Geral do Rio de Janeiro.

Palavras-Chave: neurologia brasileira, psiquiatria, neuropsiquiatria, história das neurociências.

In this year of 2012, we celebrate the centenary of the Brazilian Neurology, and, looking backward, we can see the schism that occurred between Psychiatry and Neurology. For a long time, during the $19^{\text {th }}$ century and the beginning of the $20^{\text {th }}$, there was hardly any distinction between them, because of the common scientific and practical interest in the brain and mind. The two disciplines developed together and they were both a branch of Internal Medicine. Even in Europe, at that time, many physicians practiced simultaneously both specialties ${ }^{1}$. The same occurred in Brazil, mainly at the Medical
School of Rio de Janeiro (FMRJ). In this paper, we presented how the autonomy of Neurology as a discipline happened: the academic structures/institutions and protagonists.

\section{NATIONAL HOSPICE FOR THE INSANE: BRAZILIAN NEUROPSYCHIATRIC FORMER CENTER}

The National Hospice for the Insane (NHI) was the first public institution focused specifically on mental illness in Brazil

\footnotetext{
${ }^{1}$ Neurologist, Associate Professor, Institute of Neurology, Faculty of Medicine, Universidade Federal do Rio de Janeiro (UFRJ), Rio de Janeiro RJ, Brazil; ${ }^{2}$ Neurologist, Adjunct Professor (retired), Director of Institute of Neurology, UFRJ, Rio de Janeiro RJ, Brazil.

Correspondence: Marleide da Mota Gomes; Programa de Epilepsia do Instituto de Neurologia Deolindo Couto, Universidade Federal do Rio de Janeiro; Avenida Venceslau Braz 95; 22290-140 Rio de Janeiro RJ - Brasil; E-mail:mmotagomes@acd.ufrj.br

Conflict of interest: There is no conflict of interest to declare.
}

Received 26 June 2012; Received in final form 25 July 2012; Accepted 01 August 2012 
(Fig 1). Three of the primary precursors and leading figures of the Brazilian Neurology worked over there: João Carlos Teixeira Brandão, Juliano Moreira and Antonio Austregésilo Rodrigues de Lima (Fig 2) ${ }^{2-6}$. In April 1883, after a competition, Teixeira Brandão was appointed as FMRJ Professor of Clinical Psychiatry
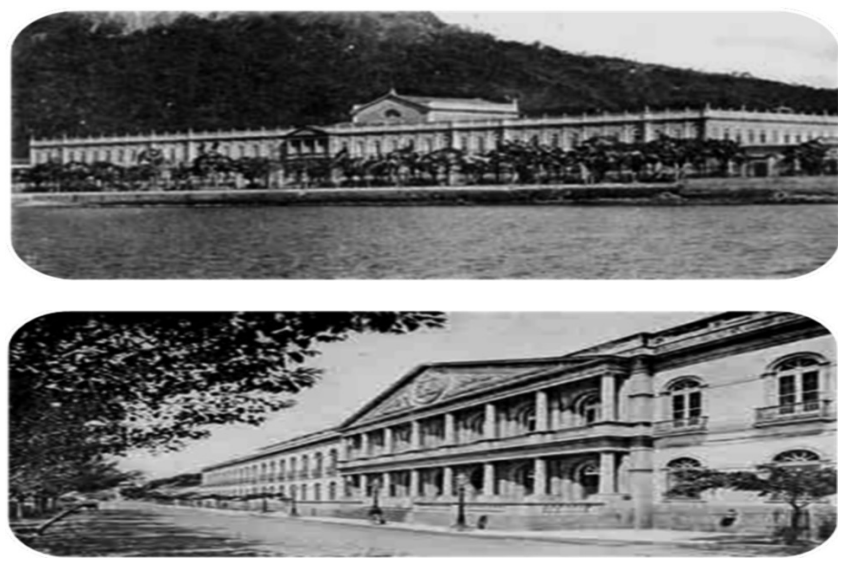

Fig 1. The Brazilian Neurology founding places, around the $20^{\text {th }}$ century beginning. (A) National Hospice for the Insane; (B) Santa Casa de Misericórdia do Rio de Janeiro. Not illustrated the Policlínica Geral do Rio de Janeiro.
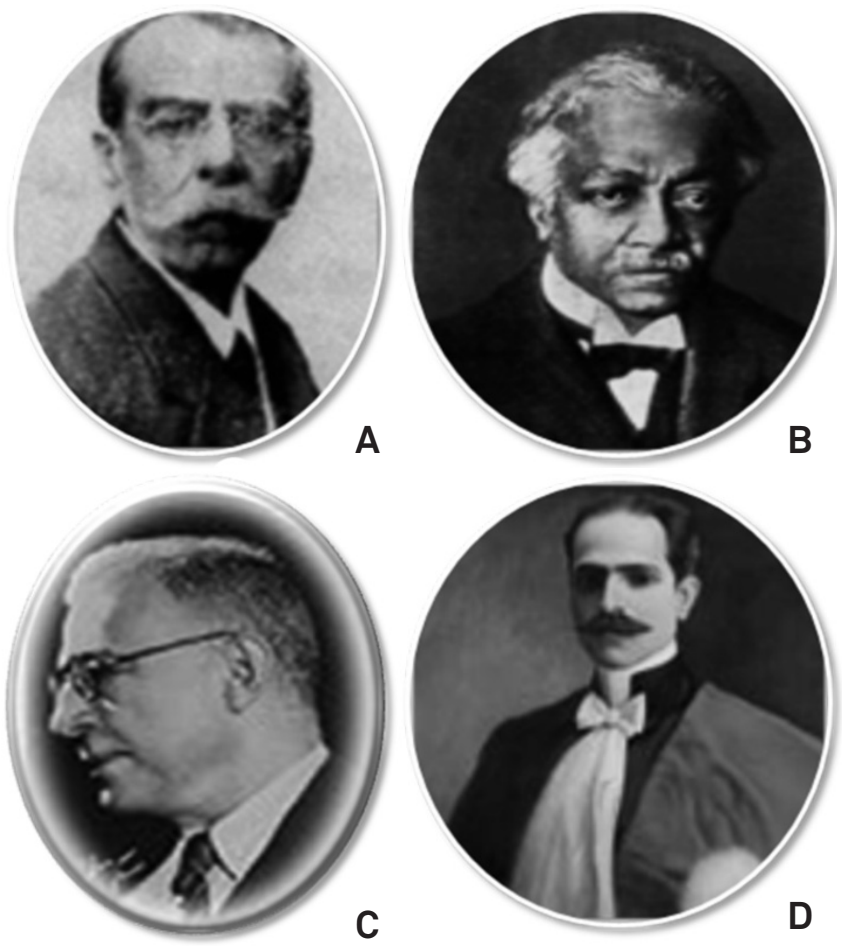

"The Brazilian Neurology father"

Fig 2. The main Brazilian Neurology precursors: A. João Carlos Teixeira Brandão (São João Marcos-RJ, 1854 - Rio, 1921), son of Felicio Viriato Brandão e Maria Flora Teixeira Brandão, B. Juliano Moreira (Salvador, 1873 - Correias-Rio, 1933), son of Manoel do Carmo Moreira Jr e Galdina Joaquina do Amaral: C. Antonio Austregésilo Rodrigues de Lima (Recife,1876Rio,1960), son of José Austregésilo Rodrigues Lima e Maria Adelaide Feitosa Lima - "father" of the Brazilian Neurology and "spiritual father" of Brazilian neurosurgery.; D. Aloysio de Castro (Rio, 1881-1959), son of Francisco de Castro, a great FMRJ professor, and Maria Joana Pereira Monteiro de Castro. and Nervous Diseases. He was also director of the NHI (18871897). In Salvador, Augusto Freire de Maia Bittencourt (18471891) was the professor of this chair (1886-1891), that was created by the Decree $n^{\circ} 3.141$ of $1882^{7}$. Teixeira Brandão was also the diffuser of the French psychiatric thinking in Brazil. He became medical doctor in 1877 with a thesis entitled "Operations claimed by narrowing of the urethra.... After practicing medicine in the province of Rio de Janeiro (1878-1880) and under the suggestion of João Vicente Torres Homem (Fig 3), he traveled to France, Germany and Italy to study Psychiatry. He was a founder of Policlínica Geral do Rio de Janeiro in 1881, working at the Service of Diseases of the Nervous System.

In Brazil, Moreira was the founder of the Brazilian scientific Psychiatry, director of the NHI (1903-1930) and very influent in the Neuropsychiatric area. More qualifications of this great Brazilian, who influenced the Neurology development, are given in other papers ${ }^{3-6}$.

Austregésilo moved to Rio de Janeiro from Pernambuco at age of 16 to attend the FMRJ, where he graduated in 1899 with his thesis "Clinical study of delirium". He worked at the NHI (1904-1910), where he was also involved in the journal and the society linked to Psychiatry and Neurology, both originated at this Hospital ${ }^{3-6}$.

\section{SANTA CASA DE MISERICÓRDIA AND POLICLIINICA GERAL DO RIO DE JANEIRO}

Austregésilo worked at Santa Casa de Misericórdia (1902-). In 1909, he was indicated by the congregation of the

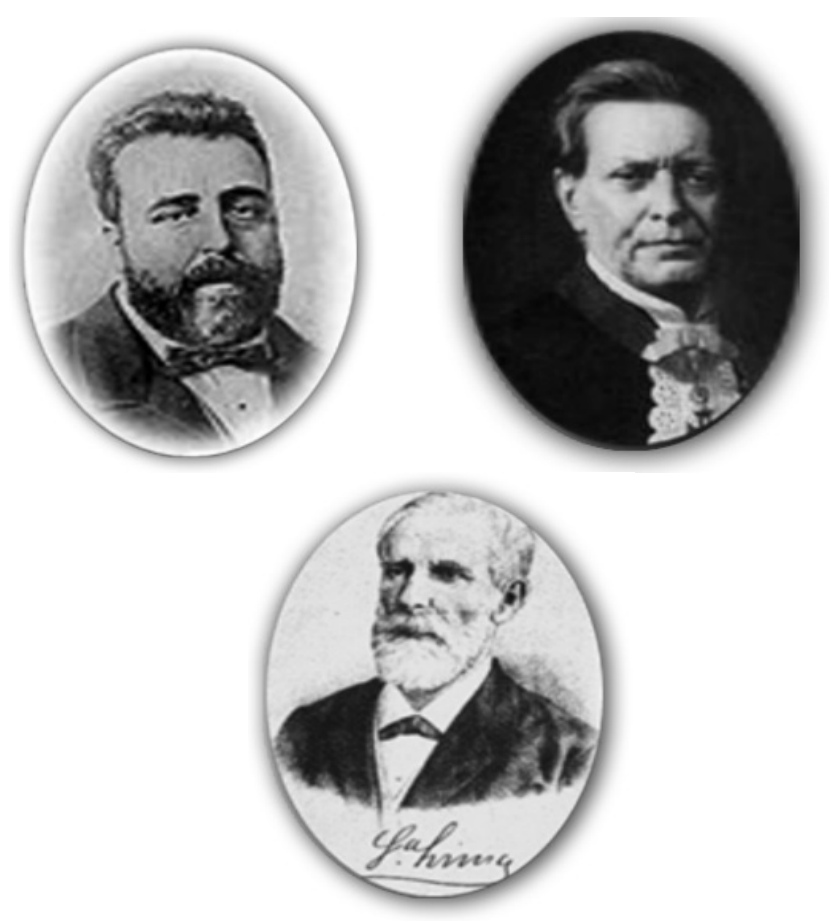

Fig 3.The authors who published the pioneers Neuro/ Psychiatry works in Brazil. 
FMRJ as substitute professor of Clinical medicine, pathology and propaedeutic clinic ${ }^{8}$. Austregésilo had as opponents in two competitions for the position of substitute professor Miguel Pereira, Aloysio de Castro, Rubião Meira and Agenor Porto: in the first, Miguel Pereira won, in the second, Aloysio de Castro (Fig 2), and at a third moment (1909), the FMRJ congregation indicated him considering the two previous competitions $^{8}$. Three years later, in 1912, he was appointed professor of the newly created cathedra of Neurology ${ }^{8}$. However, both Teixeira Brandão and his substitute, Henrique Britto de Belford Roxo (1877-1969), were against the creation of it $^{8}$. At the beginning, neurological classes were taught by Austregésilo in the dependencies of the Santa Casa de Misericórdia at the $20^{\text {th }}$ Infirmary where he was the head ${ }^{8}$. At this year, the Decree no 11.530 of 1915 officially unfolded the chair of Clinical Psychiatry and Nervous Diseases ${ }^{7}$, and Faustino Monteiro Esposel (1888-1931) was the new substitute professor ${ }^{8}$. Later, in 1926, new dependencies for the neurological courses and patients care were constructed besides those of the former Observation Pavilion transformed in Institute for Psychopathology and Psychopaths Assistance, at the backyard of the $\mathrm{NHI}^{4,6}$.

Austregésilo was president of the National Academy of Medicine, member of the Brazilian Academy of Letters (1914) and federal deputy of the state of Pernambuco (1922-1930). He had several links with national, international medical and cultural societies. He wrote numerous essays and papers on Medicine and Psychology: "Clinical study of delirium", thesis (1899); "Neurological clinic", three volumes (1917, 1923 and 1945); "Medical clinic" (1917); "The psychoneuroses" (1933); "New acquisitions in the field of Neurology" (1934); "Lanalyse mentale dans les psychoneuroses" (1936); "Mental pathology" (1948); "Psychology and Psychotherapy" (1951). Almost all of the works of Austregésilo were translated into Spanish. The complete works were published in ten volumes, edited by Editora Guanabara (1945-1947). His mental bias work is evident in his medical production, for instance, in "Hysteria and hysteroide syndrome" (1909). This was a theme of great interest in the transition from $19^{\text {th }}$ to the $20^{\text {th }}$ century, because of the difficulties to fit it in the classification systems and the intense discussion of its etiology, which had as a backdrop a gender influence. Situated at the crossroads of Psychiatry and Neurology, hysteria was for Austregésilo a subject of great interest, which inspired the Brazilian psychiatric production of the first decades of the $20^{\text {th }}$ century ${ }^{9}$. Unlike much of the Brazilian psychiatric thought at the time ${ }^{9}$, Austregésilo had positive image of women.

Aloysio de Castro was graduated (1903) with a thesis entitled "From the gait disorders and their clinical value". In 1906, he received an award for being the best student in his class, which allowed him to go to Europe to study nervous semiology. Over there, he attended the ward and laboratory of the Hôpital Bicêtre, directed by Pierre Marie (1853-1940), among others. He had attended at the Santa Casa da Misericórdia of Rio de Janeiro hospital since the time he was a third year undergraduate medical student. He helped to introduce Neurology from Paris to the $4^{\text {th }}$ Infirmary of the Santa Casa and to the Service of Clinical Medicine in Policlínica Geral do Rio de Janeiro, as quoted by Nava ${ }^{10}$. He was professor of Medical Pathology (1910) and Internal Medicine (1915), having held the latter chair until 1940, when he retired. He was director of the FMRJ (1915-1925) and worked at the Policlínica Geral do Rio de Janeiro (1907-1946), where he collected material for his monumental work, registering with film strips abnormal gaits in various nervous diseases.

Brazilian Neurology was created within the hegemonic psychiatric school, mainly at the NHI, but also at the Santa Casa de Misericórdia and Policlínica Geral do Rio de Janeiro. Antonio Austregésilo Rodrigues de Lima is its most important primordial leader.

\section{References}

1. Boller F, Barba GD. The evolution of Psychiatry and Neurology. Two disciplines divided by a common goal? In: Jeste DV, Friedman JH (eds). Psychiatry for neurologists. New Jersey: Humana Press; 2005:11-15.

2. Brandão JCT. Dicionário histórico-biográfico das ciências da saúde no Brasil (1832-1930). [cited 2012 Apr 14]. Available from: http:// www.dichistoriasaude.coc.fiocruz.br

3. Facchinetti C, Cupello P, Evangelista DF. Arquivos brasileiros de Psiquiatria, Neurologia e Ciências afins: uma fonte com muita história. Hist Cienc Saude-Manguinhos 2010;17:S527-S535.

4. Gomes MM, Cavalcanti MT. National Hospice for the Insane and the Brazilian Neurology at the beginning of the 20th century. Arq Neuropsiquiatr 2012;70(10):823-825.

5. Gomes MM, Engelhardt E. Meynert and the biological German psychiatry. Arq Neuropsiquiatr 2012;70:894-896.
6. Gomes MM. Marcos históricos da neurologia. Rio de Janeiro: Editora Científica Nacional; 1997.

7. Câmara dos deputados. Legislação. Decreto n 3.141 de 1882 e Decreto n 11.530 de 1915. [cited 2012 Apr 14]. Available from: http:// www2.camara.gov.br/atividade-legislativa/legislacao

8. Magalhães F. O centenário da Faculdade de Medicina do Rio de Janeiro 1832-1932. Rio de Janeiro:Typ. A. P. Barthel; 1932.

9. Nunes SA. Histeria e psiquiatria no Brasil da Primeira República. Hist Cienc Saude-Manguinhos 2010;17:S373-S389.

10. Nava P. Aloysio de Castro, o gentil-homem da Medicina Brasileira. Brazil-Médico 1959;45-52. 